\title{
A Study on Body Image Satisfaction in Female Emergency Medical Technicians
}

\author{
Hyean-Sook Ra ${ }^{1}$ and Jeong-Mi Park ${ }^{2 *}$ \\ ${ }^{1}$ Daegu-Kyeongbuk of Korean Aesthetic Ability Development Association, \\ ${ }^{2}$ Department of Emergency Medical Technology, Kyungil University$$
\text { 여성 구급대원의 신체이미지 만족에 관한 연구 }
$$$$
\text { 나현숙 }{ }^{1}, \text { 박정미 }{ }^{2^{*}}
$$$$
{ }^{1} \text { 피부미용능력개발협회 대경지회, }{ }^{2} \text { 경일대학교 응급구조학과 }
$$

\begin{abstract}
The purpose of this study is to evaluate what baseline characteristic is most related with body image satisfaction and identify which items are the lowest score on body image and their related behaviors in female emergency medical technicians(EMTs). Female $\operatorname{EMTs}(\mathrm{n}=96)$ working in the G provence completed a battery of questionnaires. Multiple logistic regression analysis showed that body image satisfaction was significantly associated with physical activity $(p=.007,95 \%$ CI: 2.937 19.180) in female EMTs. Subjects were most satisfied with their $\operatorname{sex}($ male or female $)(\mathrm{M}=3.34, \mathrm{SD}=0.72)$ and they were most dissatisfied with $\operatorname{sleep}(\mathrm{M}=2.61, \mathrm{SD}=0.85)$. The skin protective behavior showed significant difference according to skin concerns $(\mathrm{p}<.05)$.

요 약 연구의 목적은 여성 구급대원에게 있어서 대상자의 신체이미지(body image) 만족도에 영향을 미치는 일반적 인 특성을 파악하고 변수들과 신체이미지와의 관련성을 규명하여 이와 관련된 행동양식의 차이를 파악하는 것에 있 다. $\mathrm{G}$ 지역 소방본부 소속 여성 구급대원(n=96)을 대상으로 설문조사를 하였다. 연구결과 여성 구급대원의 신체이미지 에 가장 큰 관련성이 있는 것은 신체활동( $p=.007,95 \% \mathrm{CI}: 2.937 \sim 19.180)$ 으로 나타났고 신체활동을 많이 할수록 신체 이미지 만족도가 유의하게 높았다. 신체이미지 중 여성 $(\mathrm{M}=3.34, \mathrm{SD}=0.72)$ 에 대해 가장 만족도가 높았으나 수면 영역 $(\mathrm{M}=2.61, \mathrm{SD}=0.85)$ 에서 가장 낮은 만족도를 보였다. 피부문제에 따라 피부보호 습관에도 유의한 차이가 있었으며 (p<.05) 여성 구급대원의 신체이미지 만족도에 영향을 미치는 것으로 나타났다.
\end{abstract}

Key Words : Body image satisfaction, female EMTs, physical activity, skin protective behavior

\section{Introduction}

Body image and negative feelings about oneself are influenced positively and negatively by various external, cultural, and social comparison standards. Body image in modern society is influenced by parents and family, peer dynamics, and the media. Therefore, body image satisfaction is associated with internal biological and psychological factors such as self-esteem, interpersonal confidence, eating and exercise behaviors and emotional stability[1]. In women, high levels of negative perception of their own weight and appearance is related to higher incidence of depression, anger, stress response, anxiety, social isolation, and sexual problems[2,3].

Although a person's body satisfaction is generally not life threatening, negative self-evaluation affects overall quality of life[4]. Emergency medical technicians(EMTs) are healthcare providers of emergency medical services. EMTs are typically the first responders to emergency situations where medical care is needed. These technicians

This study was supported by the Kyungil University Grant

*Corresponding Author : Jeong-Mi Park(Kyungil Univ.)

Tel: +82-53-600-5683 email: emsjm@kiu.ac.kr

Received May 29, $2013 \quad$ Revised July 16, 2013

Accepted August 7, 2013 
are often the lifeline for patients between the location of the accident and the hospital. The job often requires 24-hour shifts and EMTs revealed high levels of occupational stress[5]. Earlier studies examined stress, risk factors and pre-hospital steps among $\operatorname{EMTs}[5,6]$ and its related symptoms. However, there is little research on body image in EMTs, even though stress is strongly related with body image[7]. EMTs are more physically demanding job than other jobs. So we hypothesized the body satisfaction of female EMTs may be related with different baseline characteristics compared with general females.

Therefore, we examined body image in female EMTs, relationship between body image satisfaction and baseline characteristic, and lowest scoring items and their related behaviors.

Some reports suggest risk factors such as smoking initiation in adolescent girls[8] and dieting concerns among women[9] are significantly associated with body image. People who regularly drink alcohol have a more negative body image than nondrinkers as well as a higher rate of death, depression, violence, suicide, and certain cancers[10]. Physical activity and exercise alleviate some symptoms of mild to moderate depression, increase self-confidence, self-control and decrease anger, depression and tension[11].

Class I in an exercise group reported more likely to be normal weight and to be healthy[11]. Generally body image is differently influenced by sociocultural factors such as age, media, social emphasis and job. Body image is also influenced by individual factors such as Body Mass Index(BMI), eating behaviors and peer pressure.

In these respects, the purpose of this study was to evaluate what baseline characteristic is most related with body image satisfaction in female EMTs and identify which items are the lowest score on body image and their related behaviors in female emergency medical technicians.

\section{Participants and methods}

\subsection{Study design and procedures}

This study is self-reported survey design to evaluate what baseline characteristic is most related with body image satisfaction and identify which items are the lowest score on body image and their related behaviors in female EMTs. Under the permission of fire service headquarters of $\mathrm{G}$ province, the survey was administered from June 9 to September 20, 2012. Returned 103 questionnaires were visually examined to ensure that most of the questions had been completed. Incomplete questionnaires were excluded for evaluation; 96 questionnaires in total were analyzed.

\subsection{Measures}

Participants' demographic characteristics, drinking, smoking, level of physical activity, skin care practices, and subjective body satisfaction were measured. Demographic variables included age, marital status, income, shift work, perceived level of sleepiness, and body mass index(BMI). BMI $\left(\mathrm{kg} / \mathrm{m}^{2}\right)$ was calculated from self-reported weight and height according to the South east Asian definition[12]: underweight if BMI was less than 18.5, normal weight if BMI was between 18.5 and 22.9, overweight if BMI was between 23.0 and 24.9, and obese if BMI was over 25.0.

The Body Cathexis Scale(BCS) was utilized to assess body image satisfaction. The BCS was developed to indicate the degree of a person's satisfaction with various parts or functions of the body. Chronbach's a for BCS was .90 in this study.

Designed by Paul F. Secord and Sidney M. Jourad, the BCS consists of a listing of 46 body parts and functions, each followed by the numbers 1 through 5[13]. 1. Have strong negative feelings and wish change could somehow be made. 2. Don't like, but can put up with. 3. Have no particular feelings one way or the other. 4. Am satisfied. 5. Consider myself fortunate. Higher scores indicate greater satisfaction with body image.

Smoking and drinking behaviors were measured by response to a question about how often participants smoked or drank alcohol. Physical activity was categorized as level I(light activity, no physical activity or less than level 2 exercise) or level II(30 minutes a day at least 5 days a week of moderate to vigorous activity such as swimming, tennis, badminton, basketball, jogging, Ping-Pong, hiking, bicycle riding, soccer, volleyball, jump rope, or squash).

Skin care behavior was measured by subjects' report of the use of skin care products(moisturizer, body lotion, 
hand cream, foot cream, body cleanser, soap, cleanser, toner, sun-screen, foundation, face powder, or two-way cake) and divided into two groups: $\leq 6$ and $7 \sim 12$ products used.

Sleepiness was measured by a Korean version of the Epworth Sleepiness Scale(ESS)[14]. The ESS asks the subject to rate his or her probability of falling asleep in different situations in daily life; higher scores indicate greater sleepiness. Score results are interpreted as follows: $1 \sim 6$ indicates sufficient sleep or low levels of sleepiness; $7 \sim 8$ indicates average sleepiness; $\geq 9$ is considered very sleepy-the subject should seek medical advice[15]. Chronbach's a for EPSS was .80 in this study.

\subsection{Data analysis}

Statistical analyses were performed using PASW Statistics, version 18(SPSS Inc.). Descriptive data was presented as counts with percentages. Simple logistic regression was used to identify the relationships among body image satisfaction scores and smoking, drinking status, physical activity, skin care behavior, and demographic variables. Risk factors with a $p$-value less than 0.20 in a simple logistic regression were included in a multiple logistic regression analysis. Results are presented with $p$-values and $95 \%$ confidence intervals(CI); significance was established at $p<.05$. Body image items and the Epworth Sleepiness Scale(ESS) were presented as mean(SD). Skin protective behavior according to skin concerns were analyzed by Pearson chi-square.

\section{Results}

\subsection{Characteristics of participants}

Demographic variables are presented in Table 1. One hundred three female emergency medical technicians were recruited for this study. Questionnaires were visually examined to ensure that most of the questions had been completed. Incomplete questionnaires were excluded; a total of 96 surveys were analyzed. Table 1 shows the distributions of age, BMI, work experience, shift work, salary, emergency call, marital status, children, sleepiness status, skin concerns, and the four daily behaviors of drinking, smoking, exercise, and skin care practices. The mean age of the study population was $32.86 \pm 4.308$ (range: $25 \sim 46)$. In terms of BMI, 4 subjects(4.2\%) were under-weight, $76(79.2 \%)$ were normal, 10(10.4\%) were overweight, and $6(6.3 \%)$ were obese. Per the demographics questions, 84 subjects(87.5\%) performed shift work, 18(18.8\%) worked on emergency call, and $52(54.2 \%)$ were married. Ninety-three subjects(96.9\%) were never-smoked; 21(21.9\%) did not drink alcohol. Fifty(52.1\%) reported physical activity level I and 46(47.9\%) reported physical activity level II. Thirty-seven(38.5\%) used $\leq 6$ cosmetics and 59(61.5\%) used $7 \sim 12$ cosmetic products. On the Epworth Sleepiness Scale(ESS), 53 subjects(55.2\%) scored $\leq 8$ in total and $43(44.8 \%)$ scored $\geq 9$. Sixty - four $(66.7 \%)$ reported skin concerns.

[Table 1] Baseline characteristics of participants

\begin{tabular}{|c|c|c|}
\hline Baseline & characteristics & $\frac{(\mathrm{N}=96)}{\mathrm{N}(\%)}$ \\
\hline \multirow{3}{*}{ Age(yrs) } & $20 \sim 29$ & $21(21.9)$ \\
\hline & $30 \sim 39$ & $68(70.8)$ \\
\hline & $\geq 40$ & $7(7.3)$ \\
\hline \multirow{4}{*}{ BMI } & $<18.5$ (underweight) & $4(4.2)$ \\
\hline & $18.5-22.9$ (normal) & $76(79.2)$ \\
\hline & $23.0-24.9$ (overweight) & $10(10.4)$ \\
\hline & $\geq 25.0$ (Obese) & $6(6.3)$ \\
\hline \multirow{2}{*}{$\begin{array}{c}\text { Work } \\
\text { experience(years) }\end{array}$} & $<5$ & $48(50.0)$ \\
\hline & $\geq 5$ & $48(50.0)$ \\
\hline \multirow{2}{*}{ Shift work } & Yes & $84(87.5)$ \\
\hline & No & $12(12.5)$ \\
\hline \multirow{2}{*}{$\begin{array}{l}\text { Emergency } \\
\text { call }\end{array}$} & Yes & $18(18.8)$ \\
\hline & No & 78(81.3) \\
\hline \multirow{2}{*}{$\begin{array}{l}\text { Marital } \\
\text { Status }\end{array}$} & Single & $44(45.8)$ \\
\hline & Married & $52(54.2)$ \\
\hline \multirow{2}{*}{ Children } & Yes & $46(47.9)$ \\
\hline & No & $50(52.1)$ \\
\hline \multirow{3}{*}{$\begin{array}{l}\text { Smoking } \\
\text { behavior }\end{array}$} & Never smoked & 93(96.9) \\
\hline & Ex-smoker & $1(1.0)$ \\
\hline & Current smoker & $2(2.1)$ \\
\hline \multirow{5}{*}{$\begin{array}{l}\text { Drinking } \\
\text { behavior }\end{array}$} & Yes & $75(78.1)$ \\
\hline & once a month & 21(21.9) \\
\hline & once a week & $30(31.3)$ \\
\hline & 2-3 times a week & $24(25)$ \\
\hline & No & 21(21.9) \\
\hline \multirow{2}{*}{$\begin{array}{c}\text { Physical } \\
\text { activity }\end{array}$} & Level I & $50(52.1)$ \\
\hline & Level II & 46(47.9) \\
\hline \multirow{2}{*}{$\begin{array}{l}\text { Skin care } \\
\text { behavior }\end{array}$} & Using $\leq 6$ cosmetic products & $37(38.5)$ \\
\hline & Using $7 \sim 12$ cosmetics & $59(61.5)$ \\
\hline \multirow{2}{*}{$\begin{array}{c}\text { Skin } \\
\text { concerns }\end{array}$} & Yes & 64(66.7) \\
\hline & No & $32(33.3)$ \\
\hline
\end{tabular}




\subsection{Relationship between Body Cathexis Scale(BCS) and baseline characteristics}

Scores the BCS and their association with baseline characteristics are shown in Table 2. Simple logistic regression analysis showed that body image satisfaction was associated with $\operatorname{BMI}(p=.191)$, occupational groups $(p=.048)$, emergency call $(p=.157)$, physical $\operatorname{activity}(p=.003)$, skin care behavior $(p=.095)$, and skin $\operatorname{concerns}(p=.134)$. Variables with $p$-values less than 0.20 in a simple logistic regression were further analyzed in a multiple logistic regression analysis. In this analysis, physical $\operatorname{activity}(p=.007, \quad 95 \% \mathrm{CI}$ : $2.937 \sim 19.180)$ was strongly associated with body image satisfaction.

\subsection{Body Cathexis Scale results}

The mean score of body image items is shown in Table 3. The total mean score of 46 items of the BCS was $135.63(\mathrm{SD}=18.83)$.

Participants were most satisfied with their sex (male or female) (mean=3.34, $\mathrm{SD}=0.723$ ) and most dissatisfied with their $\operatorname{sleep}($ mean $=2.61, \mathrm{SD}=0.851)$, skin texture (mean=2.66, $\mathrm{SD}=0.88)$, and weight $($ mean=2.66, $\mathrm{SD}=0.73)$.

\subsection{The Epworth Sleepiness Scale(ESS)}

The results from the ESS are shown in Table 4. The total mean ESS score was $8.00(\mathrm{SD}=3.32)$. Fifty-three subjects $(55.2 \%)$ scored average in sleep and 43(44.8\%) scored as very sleepy, indicating that they should seek medical advice. Subjects reported the highest levels of sleepiness when circumstances permit lying down to rest in the afternoon(mean $=1.58, \mathrm{SD}=0.820$ ).

\subsection{Skin protective behavior according to skin concerns}

Skin protective behavior according to skin concern is shown in Table 5. The use of sun $\operatorname{screen}(p<.001)$, and face $\operatorname{powder}(p=.007)$ was significant according to skin concern. For sun protection, subjects showed significant difference in carrying a parasol or wearing a hat $(p=.019)$ and wearing long sleeves $(p=.015)$. Among sun screen users, 32(44\%) reported no skin concerns, 16(22\%) reported concerns about dry skin, and $13(18 \%)$ reported concerns about pigmentation.

[Table 2] Relationship between BCS and baseline characteristics

\begin{tabular}{|c|c|c|c|c|c|}
\hline Variables & Demographic variable & Mean & SD & $p$-value* & $\begin{array}{l}p \text {-value } \\
(95 \% \mathrm{CI})^{* *}\end{array}$ \\
\hline \multirow{4}{*}{ BMI } & $<18.5$ (underweight) & 146.25 & 19.78 & \multirow{4}{*}{.191} & \\
\hline & $18.5 \sim 22.9$ (normal) & 136.75 & 17.99 & & \\
\hline & $23.0-24.9$ (overweight) & 120.30 & 20.17 & & \\
\hline & $\geq 25.0$ (obese) & 139.83 & 17.66 & & \\
\hline \multirow{3}{*}{$\begin{array}{l}\text { Occupational } \\
\text { Groups }\end{array}$} & EMT - B & 137.00 & 7.39 & \multirow{3}{*}{.048} & \\
\hline & EMT - P & 138.79 & 19.48 & & \\
\hline & Nurse & 127.38 & 16.04 & & \\
\hline \multirow{2}{*}{$\begin{array}{l}\text { Emergency callout } \\
\text { in the last week }\end{array}$} & Yes & 136.94 & 20.08 & \multirow{2}{*}{.157} & \\
\hline & No & 129.94 & 10.61 & & \\
\hline \multirow[t]{2}{*}{ Physical activity } & Level I & 130.18 & 18.19 & \multirow{2}{*}{.003} & .007 \\
\hline & Level II & 141.54 & 17.88 & & $(2.937 \sim 19.180)$ \\
\hline \multirow{2}{*}{$\begin{array}{c}\text { Skin care behavior } \\
\text { (number of cosmetic products used) }\end{array}$} & $\leq 6$ & 131.57 & 16.51 & \multirow{2}{*}{.095} & \\
\hline & $7 \sim 12$ & 138.17 & 19.86 & & \\
\hline \multirow{5}{*}{ Skin concerns } & Dry skin & 143.47 & 22.97 & \multirow{5}{*}{.134} & \\
\hline & Pigmentation & 133.80 & 18.79 & & \\
\hline & Acne & 136.42 & 19.93 & & \\
\hline & Allergy & 130.13 & 12.17 & & \\
\hline & None & 133.47 & 16.70 & & \\
\hline
\end{tabular}

${ }^{*}$ By simple logistic regression, $* *$ By multiple logistic regression analysis, variables with $p-$ values less than 0.20 in the simple logistic regression were included in the multiple logistic regression analysis

BCS: Body Cathexis Scale

BMI: Body Mass Index

EMT-B: Emergency Medical Technician-Basic

EMT-P: Emergency Medical Technician-Paramedic 
[Table 3] The items of Body Cathexis Scale

\begin{tabular}{cccc}
\hline Body Cathexis Items & Mean $(\mathrm{SD})$ & Body Cathexis Items & Mean(SD) \\
\hline Hair & $2.81(0.92)$ & Width of shoulders & $2.86(0.81)$ \\
Facial complexion & $2.81(0.85)$ & Arms & $3.13(0.78)$ \\
Hands & $3.16(0.68)$ & Chest & $2.89(0.93)$ \\
Distribution of hair over body & $3.10(0.91)$ & Eyes & $3.10(0.70)$ \\
Nose & $2.93(0.75)$ & Digestion & $2.89(0.85)$ \\
Fingers & $3.21(0.69)$ & Hips & $2.80(0.85)$ \\
Elimination & $2.95(0.89)$ & Skin texture & $2.66(0.88)$ \\
Wrists & $3.09(0.68)$ & Lips & $2.90(0.65)$ \\
Breathing & $3.23(0.65)$ & Legs & $2.99(0.94)$ \\
Waist & $3.06(0.80)$ & Teeth & $2.99(0.90)$ \\
Energy level & $2.83(0.86)$ & Forehead & $2.98(0.89)$ \\
Back & $2.78(0.95)$ & Feet & $3.17(0.72)$ \\
Chin & $3.08(0.70)$ & Sleep & $2.61(0.85)$ \\
Exercise & $2.92(0.79)$ & Voice & $3.15(0.82)$ \\
Ankles & $3.06(0.70)$ & Health & $2.92(0.79)$ \\
Neck & $3.14(0.63)$ & Sex activities & $2.81(0.61)$ \\
Shape of head & $3.06(0.72)$ & Knees & $3.04(0.85)$ \\
Body build & $2.73(0.87)$ & Posture & $2.79(0.75)$ \\
Profile & $2.69(0.85)$ & Face & $2.90(0.80)$ \\
Height & $2.92(0.94)$ & Weight & $2.66(0.73)$ \\
Age & $2.86(0.81)$ & Sex & $3.34(0.72)$ \\
Ear & $3.22(0.74)$ & Back or fiew of head & $3.14(0.72)$ \\
Appetite & $3.03(0.86)$ & Trunk & $2.77(0.78)$ \\
\hline & Total & & $135.65(18.83)$ \\
\hline
\end{tabular}

[Table 4] Scores on the Epworth Sleepiness Scale(ESS)

\begin{tabular}{cc}
\hline Situation & Mean(SD) \\
\hline Sitting and reading & $1.12(0.65)$ \\
Watching television & $0.92(0.67)$ \\
Sitting inactive in a public place (e.g., a theater or meeting) & $0.99(0.79)$ \\
As a passenger in a car for an hour without a break & $1.34(0.84)$ \\
Lying down to rest in the afternoon when circumstances permit & $1.58(0.82)$ \\
Sitting and talking to someone & $0.42(0.85)$ \\
Sitting quietly after a lunch without alcohol & $1.24(0.85)$ \\
In a car, while stopping for a few minutes in the traffic & $0.49(0.68)$ \\
\hline Total score & $8.00(3.33)$
\end{tabular}

[Table 5] Skin protective behavior according to skin concerns

$\mathrm{N}(\%)$

\begin{tabular}{|c|c|c|c|c|c|c|c|}
\hline \multirow{2}{*}{ Skin protection } & \multirow[b]{2}{*}{ Yes/No } & \multicolumn{5}{|c|}{ Skin concerns } & \multirow[b]{2}{*}{$p^{*}$} \\
\hline & & Dry skin & Pigmentation & Acne & Allergy & No concerns & \\
\hline \multirow[t]{2}{*}{ Sun screen } & Yes & $16(22.2)$ & $13(18.1)$ & $7(9.7)$ & $4(5.6)$ & $32(44.4)$ & \multirow[t]{2}{*}{$<.001$} \\
\hline & No & $3(12.5)$ & $12(50.0)$ & $5(20.8)$ & $4(16.7)$ & $0(.0)$ & \\
\hline \multirow[t]{2}{*}{ Face powder } & Yes & $3(7.9)$ & $10(26.3)$ & $2(5.3)$ & $3(7.9)$ & $20(52.6)$ & \multirow[t]{2}{*}{.007} \\
\hline & No & $16(27.6)$ & $15(25.9)$ & $10(17.2)$ & $5(8.6)$ & $12(20.7)$ & \\
\hline \multirow{2}{*}{$\begin{array}{c}\text { Parasol or } \\
\text { hat }\end{array}$} & Yes & $7(13.2)$ & $15(28.3)$ & $5(9.4)$ & $2(3.8)$ & $24(45.3)$ & \multirow{2}{*}{.019} \\
\hline & No & $1(27.9)$ & $10(23.3)$ & $7(16.3)$ & $6(14.0)$ & $8(18.6)$ & \\
\hline \multirow{2}{*}{ Long sleeves } & Yes & $1(4.0)$ & $10(40.0)$ & $2(8.0)$ & $0(.0)$ & $12(48.0)$ & \multirow[t]{2}{*}{.015} \\
\hline & No & $18(25.4)$ & $15(21.1)$ & $10(14.1)$ & $8(11.3)$ & $20(28.2)$ & \\
\hline
\end{tabular}

* The relationship between skin protective behaviors and skin concern was analyzed using Pearson's chi-square test of association. 
Subjects concerned with pigmentation comprised $50 \%$ of all subjects who did not use sunscreen. Among face powder users, 20(53\%) were subjects reporting no skin concerns, 10(26\%) reported concerns about pigmentation, $3(8 \%)$ were concerned with dry skin and allergies, and $2(5 \%)$ were concerned with acne. For sun protection, 24 participants(45\%) reported no skin concerns and 15(28\%) subjects concerned with pigmentation carried a parasol or wore a hat for sun protection; $28 \%$ of subjects reporting dry skin and $23 \%$ of subjects concerned with pigmentation did not. Twelve subjects(48\%) reporting no skin concerns, $10(40 \%)$ concerned with pigmentation, $2(8 \%)$ concerned with acne and 1(4\%) concerned with dry skin wore long sleeves for sun protection. Twenty subjects reporting no skin concerns(28\%), 18 reporting dry skin concerns(26\%), 15 concerned with pigmentation (21\%), 10 concerned with acne (14\%) and 8 concerned with allergies(11\%) did not wear long sleeves for sun protection.

\section{Discussion}

Body image is a person's judgment of his or her physical attractiveness. Negative body image in females is correlated with a higher incidence of depression, heightened anxiety, and lowered self-esteem[2,3].

Body image is a multidimensional construct that involves internal biological and psychological factors as well as external cultural and social factors[1]. Emergency medical technicians are healthcare providers of emergency medical services. EMTs are typically the first responders to emergency situations where medical care is needed. The job often requires 24-hour shifts and EMTs

skin concerns $(p=.134)$ and skin care practices $(p=.095)$ are correlated with body satisfaction in simple logistic regression. Physical activity $(p=.007,95 \% \mathrm{CI}=$ $2.937 \sim 19.180$ ) was strongly associated with body satisfaction in multiple logistic regressions. The body image dissatisfaction of general women is typically related with both individual characteristics (BMI, self-esteem, eating behaviors, and perceived family dynamics) and sociocultural factors(media and social emphasis on thinness for females and muscularity for males)[1, 16]. However the body image satisfaction in female EMTs was strongly related with physical activity.

The mean of body image scores of subjects reporting physical activity level I was 130.18 and mean of physical activity level II was 141.54, suggesting that females engaging in less physical activity experience significantly lower body satisfaction. As physical activity is related with BMI and less depression, female EMTs engaging in more exercise and physical activity may satisfied with their body. Field[17] suggested that individuals who exercised more reported better relationships and less depression than less physically active individuals. Iannotti reported that physical activity is related with weight and depression[11]. We confirmed physical activity of female EMTs enhanced body image satisfaction.

We analyzed the components of subjects' body image as measured by the Body Cathexis Scale to determine levels of satisfaction across the different items. Among all items, participants were most satisfied with their sex (male or female) (mean=3.34, $\mathrm{SD}=0.72$ ) and most dissatisfied with their weight (mean $=2.66, \mathrm{SD}=0.73$ ), skin texture $($ mean $=2.66, \quad \mathrm{SD}=0.88)$ and $\operatorname{sleep}($ mean=2.61, $\mathrm{SD}=0.85$ ). Interestingly, female EMTs were most dissatisfied with their sleep status, so we further analyzed the ESS results to measure average daytime sleepiness. The total mean score on the ESS was 8.00, meaning subjects' sleepiness status was at average levels. Although their total score was within average range, 43(44.8\%) subjects scored $\geq 9$ and satisfaction and sleep was the lowest score among all items in BCS. We attribute this finding to the fact that $84(87.5 \%)$ of the participants performed shift work. Sleep-related problems were present in all shifts and schedules[19]. Complaints are usually related to the inability to sustain high-quality sleep after a night shift. These conditions can be accompanied by intense feelings of fatigue and drowsiness as well as reduced capacity for mental functioning. Disordered sleep also affects quality of life[19]. Participants reported dissatisfaction with their weight $($ mean $=2.66)$ and skin texture (mean $=2.66)$. In BMI, under-weight females(mean $=146.25$ ) most satisfied with their body image and overweight females (mean=120.30) most dissatisfied with their body image. Many studies show that increased physical activity is positively associated with self-esteem, and self-worth[20,21]. As BMI showed association with body image satisfaction and weight was second lowest 
score in BCS items, subjects need to control their weight to improve the body satisfaction and quality of life. Skin texture $($ mean=2.66) was also the second lowest score in BCS items and subjects who used more cosmetic products more satisfied with their body. Dry skin subjects were most satisfied their body and skin care behavior and skin concerns were with $p$-values less than 0.20 in the simple logistic regression. So we further analyzed the relationship between skin protective behavior and skin concerns. Interestingly, we found that subjects who reported having no skin concerns tended to use more cosmetic items. Subjects reporting no skin concerns used more sun-screen than those concerned with pigmentation, dry-skin, acne, and allergies $(p<.001)$. Sun-screen provides UV protection and brighten the skin. Subjects reporting no skin concerns reported more use of face powder than did subjects with concerns about dry skin, pigmentation, acne, and allergies $(p=.007)$. Face powder is used to cover small flaws, control oily shine, set foundation, and to protect the skin from UV rays. Ultraviolet radiation is the most damaging environmental factor to the appearance of skin[22]. Subjects reporting no skin concerns were more likely to protect their skin from the sun by carrying a parasol or wearing a $\operatorname{hat}(p=.019)$ or long sleeves $(p=.015)$, compared to those reporting other skin concerns. As skin texture was the second lowest score in the BCS items and more skin caring subjects were more satisfied their body image than less skin caring subjects, females also need to care and protect their skin to improve body image and quality of life.

\section{Conclusion}

In conclusion, our findings confirmed the existence of a significant association between physical activity and positive body image in female EMTs. Participants were most dissatisfied with their sleep status, weight, and skin texture. Therefore, disease prevention and health promotion programs could provide an opportunity to increase sleep satisfaction and physical activity. Further, education concerning skin care is helpful for minimizing the risks to skin and quality of life.

\section{References}

[1] Cash TF, Morrow JA and Hrabovsky JI, "How has body image changed? A cross sectional investigation of college women and men from 1983 to 2001", Journal of Consulting and Clinical Psychology, Vol. 6, pp.1081-1089, 2004.

DOI: http://dx.doi.org/10.1037/0022-006X.72.6.1081

[2] Hamilton SR, "A relationship between perceived body image and depression: How college women see themselves may affect depression", Student Journal of Psychological Science, Vol. 1, No. 1, pp.13-20, 2008.

[3] Carpenter KM, Hasin, DS, Allison DB and Faith MS, "Relationships between obesity and DSM-IV major depressive disorder, suicide ideation, and suicide attempts; Results from a general population study", American Journal of Public Health, Vol. 90, No. 2, pp.251-257, 2000. DOI: http://dx.doi.org/10.2105/AJPH.90.2.251

[4] Natalia S and Sharon MB, "Gender differences in body satisfaction: An examination of familial and individual level variables", Family Science Review, Vol. 16, No. 1, pp.57-73, 2011.

[5] Dolly E and Siebert D, "Occupational risk factors in the emergency medical services", Prehospital and Disaster Medicine, Vol. 24, No. 5, pp.422-429, 2009.

[6] Sterud T, Hem E, Ekeberg O and Lau B, "Occupational stressors and its organizational and individual correlates; a nationwide study of Norwegian ambulance personnel", BMC Emergency Medicine, Vol .8, p.16, 2008.

DOI: http://dx.doi.org/10.1186/1471-227X-8-16

[7] Laitinen J, Ek E and Sovio, U, "Stress-related eating and drinking behavior and body mass index and predictors of this behavior", Preventive Medicine, Vol. 34, No. 1, pp.29-39, 2002.

DOI: http://dx.doi.org/10.1006/pmed.2001.0948

[8] Stice E and Shaw H, "Prospective relations of body image, eating, and affective disturbances to smoking onset in adolescent girls: How virginia slims", Journal of Consulting Clinical Psychology, Vol. 71, No. 1, pp.129-135, 2003.

DOI: http://dx.doi.org/10.1037/0022-006X.71.1.129

[9] Saules KK, Pomerleau CS, Snedecor SM, Mehringer AM, Shadle MB, Kurth C and Krahn DD, "Relationship of onset of cigarette smoking during college to alcohol use, dieting concerns, and depressed mood: results from the Young Women's Health Survey", Addictive Behaviors, Vol. 29, No. 5, pp.893-899, 2004.

DOI: http://dx.doi.org/10.1016/j.addbeh.2004.02.015 
[10] Hyeansook R and Sunok J, "Impact of Drinking Behavior on Body Image and Skin Care Behavior in Women", Korean Journal of Aesthetics and Cosmetology, Vol. 10, No. 2, pp.445-454, 2012.

[11] Iannotti R and Wang J, "Patterns of Physical Activity, Sedentary Behavior, and Diet in U.S. Adolescents", Sample Issue, Journal of Adolescent Health, 2013. DOI: http://dx.doi.org/10.1016/j.jadohealth.2013.03.007

[12] Shiwaku K, Anuurad E, Enkhmaa B, Nogi A, Kitajima $\mathrm{K}$, Shimono $\mathrm{K}$, Yamane $\mathrm{Y}$ and Oyunsuren $\mathrm{T}$, "Overweight Japanese with body mass indexes of 23.0-24.9 have higher risks for obesity-associated disorders: a comparison of Japanese and Mongolians", International Journal of Obesity and Related Metabolic disorders, Vol. 28, No. 1, pp.152-158, 2004. DOI: http://dx.doi.org/10.1038/sj.ijo.0802486

[13] Secord PF and Jourard SM, "The appraisal of body-cathexis: body-cathexis and the self", Journal of Consulting Psychology, Vol. 17, No. 5, pp.343-347, 1953. DOI: http://dx.doi.org/10.1037/h0060689

[14] Yongwon C, Joohwa L, Hyokyung S, Seunghoon L, Chol S and Murray WJ, "The reliability and validity of the Korean version of the Epworth sleepiness scale" Sleep Breath, Vol. 15, No. 3, pp.377-384, 2011. DOI: http://dx.doi.org/10.1007/s11325-010-0343-6

[15] Johns MW, "A new method for measuring daytime sleepiness; the Epworth sleepiness scale", Sleep, Vol.14, No.6, pp.540-545, 1991.

[16] Peterson KA, Paulson SE, and Williams KK, "Relations of eating disorder symptomology with perceptions of pressures from mother, peers, and media in adolescent girls and boys", Sex Roles, Vol. 57, pp.629-639, 2007.

DOI: http://dx.doi.org/10.1007/s11199-007-9296-z

[17] Field T, "Exercise is positively related to adolescent's relationship and academics" Adolescence, Vol. 36, No. 141, pp.105-110. 2001.

[18] Flo E Pallesen S, Akerstedt T, Mageroy N, Moen BE, Gronli J, Nordhus IH and Bjorvatn B, "Shift-related sleep problems vary according to work schedule", Occupational and Environmental Medicine, Vol. 70, No. 4, pp.238-245, 2013.

DOI: http://dx.doi.org/10.1136/oemed-2012-101091

[19] Bajraktarov S, Novotni A, Manusheva N, Nikovska DG, Miceva-Velickovska E and Zdraveska N, Samardjiska VC, Richter KS, "Main effects of sleep disorders related to shift work-opportunities for preventive programs", EPMA Journal, Vol. 2, No. 4, pp.365-370, 2011

DOI: http://dx.doi.org/10.1007/s13167-011-0128-4

[20] Goldfield GS, Mallory R, Parker T, Cunningham T, Legg C, Lumb A, Parker K, Prud'homme D and Adamo $\mathrm{KB}$, "Effects of modifying physical activity and sedentary behavior on psychosocial adjustment in overweight/obese children", Journal of Pediatric Psychology, Vol. 32, No. 7, pp.783-793, 2007.

DOI: http://dx.doi.org/10.1093/jpepsy/jsm017

[21] Kirkcaldy BD, Shephard RJ and Siefen RG, "The relationship between physical activity and self-image and problem behaviour among adolescents", Social Psychiatry and Psychiatric Epidemiology, Vol. 37, No. 11, pp.544-550, 2002.

DOI: http://dx.doi.org/10.1007/s00127-002-0554-7

[22] Matsumura Y and Honnavara NA, "Toxic effects of ultraviolet radiation on the skin", Toxicology and Applied Pharmacology, Vol. 195, No. 3, pp.298-308, 2004.

DOI: http://dx.doi.org/10.1016/j.taap.2003.08.019

\section{Hyean-Sook Ra}

[Regular member]

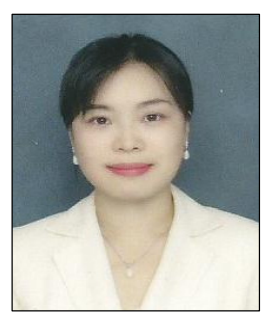

- Aug. 2007 : Catholic Univ. of Daegu., Biology, PhD

- Sep. $2006 \sim$ Feb. 2011 : Sunlin Univ., Dept. of Dermatology and Beauty, Professor

- Jan. $2013 \sim$ current : DaeguKyeongbuk of Korean Aesthetic Ability Development Association, Consultant

$<$ Research Interests $>$

Cosmetic industry, Skin-care industry, Body -image

\section{Jeong-Mi Park}

[Regular member]

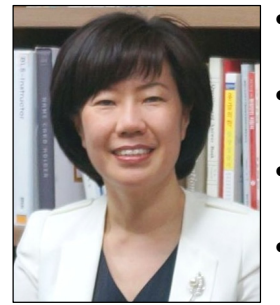

- Feb. 1992 : Kyungpook National Univ., Nursing, MS

- Aug. 2006 : Kyungpook National Univ., Nursing, PhD

- Mar. $1995 \sim$ Aug. 2011 : Sunlin Univ., Dept. of EMT, Professor

- Sep. $2011 \sim$ current : Kyungil Univ., Dept. of EMT, Professor

$<$ Research Interests $>$

Emergency Medical Service, CPR, ACLS, PTSD 